\title{
PENGGUNAAN MODEL PEMBELAJARAN DISCOVERY LEARNING DALAM PENINGKATAN HASIL BELAJAR SISWA DI SEKOLAH DASAR
}

\author{
Nabila Yuliana \\ Program Studi Pendidikan Guru Sekolah Dasar, Fakultas Keguruan dan Ilmu Pendidikan \\ Universitas Kristen Satya Wacana Salatiga, Indonesia \\ Email: 292015092@student.uksw.edu
}

\begin{abstract}
ABSTRAK
Pendidikan di Indonesia kini dituntut untuk lebih baik lagi terkait hasil belajar siswa. Dimana hasil belajar sangat dipengaruhi dengan bagaimana guru memilih model penyampaian materi di kelas. Maka dari itu artikel ini peneliti buat dengan tujuan memberikan referensi terkait model pembelajaran yang dalam penerapannya telah terbukti meningkatkan hasil belajar siswa di sekolah dasar. Di Indonesia sendiri memiliki berbagai macam model pembelajaran yang tentunya memiliki kelebihan dan kekurangan masing-masing. Pada kesempatan ini peneliti hanya memilih satu model pembelajaran yaitu discovery learning. Maka peneliti melakukan riset dengan metode meta analisis yang merupakan salah satu upaya merangkum berbagai hasil penelitian dengan studi dokumen 6 data terkait penggunaan model pembelajaran discovery learning yang dipublikasikan di jurnal nasional. Dari penelitian yang dilakukan terbukti bahwa model discovery learning mampu membantu meningkatkan keaktifan siswa dalam proses pembelajaran dengan siswa menemukan informasi sendiri sehingga menunjukkan peningkatan hasil belajar siswa baik di Sekolah Dasar maupun jenjang pendidikan di atasnya.
\end{abstract}

Kata Kunci: Hasil belajar, model, discovery learning

\begin{abstract}
Education in Indonesia is now required to be better related to student learning outcomes. Where learning outcomes are greatly influenced by how teachers choose the delivery model of the material in the classroom. Therefore this article the researcher made with the aim of providing references related to the model of learning in the application has been proven to improve student learning outcomes in primary schools. In Indonesia it self has a variety of learning models that certainly has advantages and disadvantages of each. On this occasion researchers only choose one model of learning that is discovery learning. So researchers do research with metaanalysis method which is one effort to summarize the various research results with document studies 6 data related to the use of discovery learning learning model published in the national journal. From the research conducted proved that the discovery learning model can help improve the activity of students in the learning process with students find their own information so as to show improvement in student learning outcomes both in elementary school and educational level on it.
\end{abstract}

Key words: Learning outcomes, models, discovery learning.

\section{PENDAHULUAN}

Pendidikan saat ini guru dituntut bekerja lebih keras dalam meningkatkan hasil belajar siswa ini berhubungan dengan bagaimana guru menyampaikan pembelajaran kepada siswa. Cara penyampaian materi dapat dilakukan guru dengan memanfaatkan berbagai macam model, pendekatan dan strategi yang dapat digunakan dalam merancang pembelajaran.

Menurut Pusat Penilaian Pendidikan (2009), hasil ujian nasional di Kabupaten 
Wonogiri Tahun 2009 dengan jumlah 11.091 peserta, yang tidak lulus sebanyak 124 siswa $(1,929 \%)$ dengan distribusi nilai siswa pada pelajaran matematika di bawah nilai 6 sebanyak 1.447 siswa dengan nilai terendah 1,25. Hal ini menunjukkan bahwa hasil belajar cukup rendah. Selain itu terungkap beberapa permasalahan yang teridentifikasi menyebabkan rendahnya hasil belajar karena lemahnya pelaksanaan proses pembelajaran yang diterapkan guru. Dapat dikatakan bahwa pembelajaran yang dilakukan oleh guru masih dilakukan secara konvensional. Para guru belum sepenuhnya melaksanakan pembelajaran secara aktif dan kreatif dalam melibatkan siswa dan masih didominasi metode ceramah dan pemberian tugas. Selain itu, dalam proses pembelajaran kebanyakan guru hanya terpaku pada buku teks sebagai satu-satunya sumber belajar mengajar.

Terkait dengan pemanfaatan model, pendekatan dan strategi yang ada sebagai yang memiliki pengaruh cukup besar pada peningkatan hasil belajar siswa. Maka peneliti melalukan penelitian terhadap model pembelajaran discovery learning karena penemuan sendiri yang dilakukan oleh siswa terkadang memberikan persepsi yang berbeda. Penelitian dilakukan dengan penelitian meta analisis yang mengumpulkan data dari berbagai penelitian lain kemudian disimpulkan apakah model discovery learning dapat meningkatkan hasil belajar siswa.

Menurut Durajad (2008) Model Discovery learning adalah teori belajar yang didefinisikan sebagai proses pembelajaran yang terjadi bila pelajar tidak disajikan dengan pelajaran dalam bentuk finalnya, tetapi diharapkan mengorganisasi sendiri. Sedangkan menurut Effendi (2012) Discovery learning merupakan suatu pembelajaran yang melibatkan peserta didik dalam pemecahan masalah untuk pengembangan pengetahuan dan ketrampilan.

Dari teori di atas peneliti menyimpulkan bahwa discovery learning merupakan proses pembelajaran yang tidak diberikan keseluruhan melainkan melibatkan siswa untuk mengorganisasi, mengembangkan pengetahuan dan keterampilan untuk pemecahan masalah. Sehingga dengan penerapan model discovery learning dapat meningkatkan kemampuan penemuan individu selain itu agar kondisi belajar yang awalnya pasif menjadi lebih aktif dan kreatif. Sehingga guru dapat mengubah pembelajaran yang awalnya teacher oriented menjadi student oriented.

Menurut Sinambela (2017) langkahlangkah Pelaksanaan Pembelajaran Discovery learning yaitu: Pertama, Stimulation (pemberian rangsangan). Siswa diberikan permasalahan di awal sehinga bingung yang kemudian menimbulkan keinginan untuk menyelidiki hal tersebut. Pada saat itu guru sebagai fasilitator dengan memberikan pertanyaan, arahan membaca teks, dan kegiatan belajar terkait discovery.

Kedua, problem statement (pernyataan/ identifikasi masalah). Tahap kedua dari pembelajaran ini adalah guru memberi kesempatan kepada siswa untuk mengidentifikasi sebanyak mungkin kejadian-kejadian dari masalah yang relevan dengan bahan pelajaran, kemudian salah satunya dipilih dan dirumuskan dalam bentuk hipotesis (jawaban sementara atas pertanyaan masalah)

Ketiga, data collection (Pengumpulan Data), berfungsi untuk membuktikan terkait pernyataan yang ada sehingga siswa berkesempatan mengumpulkan berbagai informasi yang sesuai, membaca sumber belajar yang sesuai, mengamati objek terkait masalah, wawancara dengan narasumber terkait masalah, melakukan uji coba mandiri.

Keempat, data processing (Pengolahan Data), merupakan kegiatan mengolah data dan informasi yang sebelumnya telah didapat oleh siswa. Semua informai yang didapatkan semuanya diolah pada tingkat kepercayaan tertentu.

Kelima, verification (Pembuktian) yaitu kegiatan untuk membuktikan benar atau tidaknya pernyataan yang sudah ada sebelumnya. yang sudah diketahui, dan dihubungkan dengan hasil data yang sudah ada.

Keenam, generalization (menarik kesimpulan/generalisasi). Tahap ini adalah menarik kesimpulan dimana proses tersebut 
menarik sebuah kesimpulan yang akan dijadikan prinsip umum untuk semua masalah yang sama Berdasarkan hasil maka dirumuskan prinsip-prinsip yang mendasari generalisas

Dalam penelitian yang peneliti lakukan dengan mengambil data dari beberapa sumber penelitian yang sebelumya telah dilakukan. Dari data tersebut nantinya peneliti akan membuat kesimpulan berdasarkan hasil penelitian. Kesimpulan tersebut akan menunjukkan apakah dengan penggunaan model pembelajaran discovery learning memberikan dampak baik dalam peningkatan hasil belajar siswa dari proses pembelajaran.

Kelebihan pada model discovery learning dapat disimpulkan sebagai berikut: a) Membantu siswa untuk memperbaiki dan meningkatkan keterampilan-keterampilan dan proses-proses kognitif, b) Model ini memungkinkan siswa berkembang dengan cepat dan sesuai dengan kecepatannya sendiri, c) Meningkatkan tingkat penghargaan pada siswa, karena unsur berdiskusi, d) Mampu menimbulkan perasaan senang dan bahagia karena siswa berhasil melakukan penelitian, dan e) Membantu siswa menghilangkan skeptisme (keragu-raguan) karena mengarah pada kebenaran yang final dan tertentu atau pasti

Sementara itu kekurangannya menurut Kemendikbud (2013) adalah (1) model ini menimbulkan asumsi bahwa ada kesiapan pikiran untuk belajar. Bagi siswa yang kurang memiliki kemampuan kognitif yang rendah akan mengalami kesulitan dalam berfikir abstrak atau yang mengungkapkan hubungan antara konsep-konsep, yang tertulis atau lisan, sehingga pada gilirannya akan menimbulkan frustasi. (2) Model ini tidak cukup efisien untuk digunakan dalam mengajar pada jumlah siswa yang banyak hal ini karena waktu yang dibutuhkan cukup lama untuk kegiatan menemukan pemecahan masalah. (3) Harapan dalam model ini dapat terganggu apabila siswa dan guru telah terbiasa dengan cara lama. Dan (4) model pengajaran discovery ini akan lebih cocok dalam pengembangkan pemahaman, namun aspek lainnya kurang mendapat perhatian.

\section{METODE PENELITIAN}

Penelitian ini menggunakan metode meta analisis yaitu upaya merangkum berbagai hasil penelitian dengan studi dokumen yang digunakan peneliti yaitu 6 data terkait penggunaan model pembelajaran discovery learning yang dipublikasikan di jurnal nasional yang kemudian dipelajari. Beberapa hasil penemuan ini terdapat dari pengumpulan data penelitian pada jurnal dari berbagai sumber yang mencangkup wilayah Indonesia karena peneliti ingin memberikan referensi penggunaan model yang dapat digunakan secara nasional dan tidak terfokus pada satu wilayah saja. Pengumpulan data ini melalui penelusuran di jurnal nasional dengan kata kunci pengumpulan data yang digunakan yaitu, proses pembelajaran, hasil belajar, model discovery learning. Data yang terkumpul akan dianalisis dengan menggunakan teknik analisis deskriptif kualitatif. Dari sekian banyak sumber, dipilihlah sumber yang sesuai dengan pembahasan yang akan disampaikan peneliti dalam artikel ini. Dalam sumber yang di pilih oleh peneliti hasil yang didapatkan termuat dalam bentuk kuantitatif untuk mengukur besar pengaruh penggunaan model pembelajaran discovery learning di sekolah dasar.

\section{HASIL DAN PEMBAHASAN}

Data yang diperoleh peneliti yaitu 6 jurnal terkait penerapan discovery learning sebagai berikut.

Pertama, Jurnal dengan judul Penerapan Model Discovery learning sebagai Upaya Meningkatkan Kemampuan Menulis Teks Cerita Petualangan Siswa Kelas IV Sekolah Dasar yang dilakukan oleh Vivi Novita Sari dan Wahyu Sukartiningsih yang dilakukan pada kelas IV di SDN Babatan I/456 Surabaya dengan siswa sebanyak 26 orang. Metode yang digunakan peneliti yaitu penelitian tindakan kelas (PTK) yang dilaksanakan dalam dengan dua siklus. Dari penelitian didapatkan hasil yaitu pada siklus I ketuntasan hasil belajar siswa pada siklus I memperoleh persentase sebanyak $73,07 \%$ atau 19 siswa yang tuntas belajar, sedangkan 7 siswa tidak tuntas belajar. Dengan data yang telah didapatkan 
menunjukkan bahwa pembelajaran pada siklus I belum berhasil karena belum memenuhi standar ketuntasan yang telah ditetapkan yaitu $80 \%$. Oleh karena itu dilanjutkan pada siklus II, dan didapatkan hasil pada siklus II mencapai persentase sebanyak $84,61 \%$ atau 22 siswa yang telah tuntas belajar dan 4 siswa tidak tuntas. Hal ini menunjukkan hasil siklus II sudah baik sekali dan ketuntasan hasil belajar siswa pada siklus II telah mencapai persentase yang ditetapkan pada indikator keberhasilan.

Kedua, Jurnal Peningkatan Hasil Belajar Metode Discovery Pembelajaran IPA Kelas IV SDN 03 Sungai Ambawang Kubu Raya oleh Agus Supriyadi yang dilakukan di kelas IV SDN 03 Sungai Ambawang Kubu Raya dengan jumlah siswa sebanyak 27 orang. Metode yang digunakan yaitu penelitian tindakan kelas (PTK) yang dilaksanakan dalam dua siklus. Dari penelitian didapatkan hasil yaitu diketahui bahwa guru sudah cukup baik dalam melaksankan pembelajaran yaitu dengan nilai 75 , dari uraian tersebut bahwa guru sudah cukup baik dalam menerapkan pembelajaran sesuai RPP yang telah ditentukan pada pembelajaran yang dilaksankan khsusnya pada pembelajaran bentuk daun dan fungsinya melalui metode penemuan (discovery) Berdasarkan data tersebut diatas diketahui bahwa secara keseluruhanr kegitan pembelajaran telah dilaksanakan oleh guru dalam kegitan pembelajaran IPA materi bentuk daun dan fungsinya melalui metode penemuan (discovery) yaitu sebesar $100 \%$ Berdasarkan data tersebut diketahui bahwa sebagian besar kegiatan telah dilaksanakan oleh guru dalam kegiatan pembeljarannya yaitu pada pembelajaran bentuk daundan fungsinya dengan metode penemuan (discovery learning) yaitu sebesar 97,76\% .

Dari siklus II data diketahui bahwa guru sudah sangat baik setelah siklus ke II dalam melaksanaan pembelajaran yaitu ditunjukan dengan nilai 95 dari uraian tersebut diketahui bahwa guru selalu menerapkan pembelajaran sesuai dengann RPP yang telah ditetapkann pada pembelajaran yang akan dilaksanakan khususnnya pada pembelajaran bentuk daun dan fungsinya dengan metode discovery learning, baik dalm pra pembelajaran hingga menutup pembelajaran.

Ketiga, Jurnal Pengaruh Model Discovery learning Terhadap Pemahaman Konsep IPA dan Sikap Ilmiah Siswa SMP oleh Widiadnyana, Sadia, dan Suastra yang dilakukan di kelas VII SMP Negeri 3. Metode yang digunakan yaitu penelitian eksperimen yang dilaksanakan dalam tiga uji hipotesi. Dari penelitian didapatkan hasil yaitu pada analisis uji hipotesis pertama, terdapat perbedaan pemahaman konep IPA dan sikap ilmiah siswa secara bersamaan antara siswa yang mengikuti model discovery learning dengan siswa yang mengikuti model pengajaran langsung. Hal ini dikarenakan tahapan-tahapan dari model discovery learning dapat mengembangkan sikap ilmiah dan pemahaman konsep.

Pada analisis hipotesis kedua, bahwa model discovery learning berpengaruh terhadap pemahaman konsep IPA dan secara signifikan rata-ratanya lebih tinggi dibandingkan pada model pengajaran langsung. Hal ini dikarenakan discovery learning didasari oleh teori konstrutivis, siswa harus membangun sendiri pengetahuan di dalam benaknya.

Dalam uji hipotesis ketiga ditemukan, bahwa terdapat perbedaan sikap ilmiah secara signifikan antara siswa yang mengikuti model discovery learning dengan model pengajaran langsung. Pada model discovery learning, rasa ingin tahu dapat muncul pada setiap sintak model pembelajaran ini. Mulai dari awal pada sintak stimulation, dengan menghadapkan permasalahan tentang topik yang akan dipelajari, siswa sudah terangsang ingin mengetahui lebih banyak. Kemudian pada sintak problem statement, siswa akan merasa penasaran akan kebenaran hipotesis yang dirumuskan. Selanjutnya pada sintak data collection, antusias siswa untuk mengetahui sangat besar terkait dengan apa yang terjadi dari kegiatan eksperimen yang dilakukan. Begitu pula pada sintak data processing, verification, maupun generalization. Sintaksintak ini memunculkan rasa ingin tahu siswa karena melalui sintak-sintak ini siswa 
akan dapat mengetahui hasil dari proses ilmiah yang telah dilakukan.

Keempat, Jurnal Pengaruh Model Pembelajaran Discovery learning dan Minat Terhadap Hasil Belajar IPA Siswa oleh Made Putrayasa, H. Syahruddin, dan Gege Margunayasa yang dilakukan di kelas V SD Desa Bontihing Kecamatan Kubutambahan. Metode yang digunakan yaitu penelitian eksperimen yang dilaksanakan dalam empat uji hipotesi. Dari penelitian didapatkan hasil yaitu

Dari pengujian hipotesis pertama, hipotesis nul ditolak dan hipotesis alternatif diterima. Ini berarti terdapat perbedaan hasil belajar IPA yang signifikan antara kelompok siswa yang mengikuti pembelajaran dengan model discovery learning dan kelompok siswa yang mengikuti pembelajaran dengan pembelajaran konvensional.

Pengujian hipotesis kedua, hipotesis nul ditolak dan hipotesis alternatif diterima. Ini berarti terdapat pengaruh interaksi yang signifikan antara model pembelajaran dan minat terhadap hasil belajar IPA siswa.

Pengujian hipotesis ketiga, hipotesis nul ditolak dan hipotesis alternatif diterima. Ini berarti pada kelompok siswa yang memiliki minat tinggi, terdapat perbedaan hasil belajar IPA yang signifikan antara kelompok siswa yang mengikuti pembelajaran dengan model discovery learning dengan kelompok siswa yang mengikuti pembelajaran dengan pembelajaran konvensional.

Pengujian hipotesis keempat, hipotesis nul diterima dan hipotesis alternatif ditolak. Ini berarti pada kelompok siswa yang memiliki minat rendah, tidak terdapat perbedaan hasil belajar IPA yang signifikan antara kelompok siswa yang mengikuti pembelajaran dengan model discovery learning dan kelompok siswa yang mengikuti pembelajaran dengan pembelajaran konvensional.

Hasil yang diperoleh tersebut sejalan dengan pendapat dari Susanto (2013:58) yang mengatakan bahwa: "minat memegang peranan penting dalam menentukan arah, pola dan dimensi berpikir seseorang dalam segala aktivitasnya, termasuk dalam belajar". Maka minat memiliki pengaruh terhadap belajar hal ini karena bahan pelajaran tidak sesuai dengan minat siswa akan berdampak pada cara belajar siswa yang kurang serius.

Kelima, Jurnal Pengaruh Metode Discovery learning untuk Meningkatkan Representasi Matematis dan Percaya Diri Siswa oleh Nurdin Muhamad yang dilakukan di kelas VII SMPIT Wasilah Intelegensia Garut. Metode yang digunakan yaitu penelitian mixed method. Dari penelitian didapatkan hasil yaitu nilai ratarata pretest kelas yang mendapat pembelajaran dengan metode discovery learning berada pada nilai rata-rata 30,76 , nilai rata-rata siklus I meningkat menjadi 67,50, pada siklus II nilai rata-rata mengalami kenaikan dengan nilai 79,50, pada siklus III mengalami peningkatan pula dengan nilai 86,33 sedangkan pada postes mengalami penurunan 4,06 menjadi 82,27. Penurunan nilai rata-rata yang terjadi pada postes bukan diakibatkan kemampuan representasi dan percaya diri siswa menurun, tetapi lebih diakibatkan soal yang diberikan berbeda karena mencangkup soal dari ketiga siklus serta melibatkan perhitungan dan ketepatan konsep sehingga soal pretes maupun postes cukup sulit dan komplek.

Dengan demikian terlihat bahwa metode discovery learning dapat meningkatkan kemampuan representasi matematis dan percaya diri siswa, ini terlihat dari nilai rata-rata ulangan materi garis dan sudut, segitiga pada permasalahan dipenelitian lebih kecil dibandingkan dengan hasil postes yaitu dari nilai 66 menjadi 82 .

Keenam, Jurnal Penerapan Model Pembelajaran Discovery learning untuk Meningkatkan Hasil Belajar PKN Siswa oleh Ni Luh Rismayani, Sukadi, dan I Nyoman Pursika yang dilakukan di kelas $\mathrm{X}$ SMA Negeri 1 Sukasada dengan jumlah murid 24 orang.. Metode yang digunakan yaitu penelitian tindakan kelas (PTK) yang dilaksanakan dalam dua siklus. Dari penelitian didapatkan hasil yaitu siklus I dilaksanakan dalam tiga kali pertemuan yaitu pertemuan pertama dan kedua pemberian materi pertemuan tiga tes akhir siklus. Hasil evaluasi siklus I yang diperoleh dari tes hasil belajar siklus satu tersebut 
adalah rata-rata hasil belajar 78.3, daya seap 78,3\% sedangkan ketuntasan klasikal 66,6\% ini mnunjukkan bahwa ketuntasan hasil belajar siswa masih rendah. Oleh karena itu perlu adanya perbaikan yang dilakukan pada siklus II

Pelaksanaan penelitian siklus II dilakukan hampir sama dengan siklus I yang terdiri dari tahap perencanaan, pelaksanaan, evaluasi dan refleksi pelaksanaan siklus II dilkukan lebih maksimal dibandingkan dengan siklus I untuk melakukan perbaikan dari pelaksanaan siklus I. Dalam siklus II ini dilakukan dua kali pertemuan yaitu pertemuan pertama pemberian materi dan pertmuan kedua tes akhir siklus. Berdasarkan hasil refleksi dn perbaikan dari siklus I maka di siklus II ini rata-rata hasil belajar siswa yaitu 87, 5 daya sera 87, 5 dan ketuntasan hasil belajar siswa telah mencapai $100 \%$. Ini menunjukkan penelitian dapat dikatakan berhasil karena hasil belajar yang diperoleh pada silkus II telah mencapai ketuntasan $100 \%$ dan rata-rata hasil beajar siswa berada di atas KKM.

Berdasarkan sumber data penelitian sebelumnya, hasil analisis terkait model discovery learning terkait peningkatan hasil belajar siswa dapat diperiksa pada Tabel 1 . berikut ini.

Tabel 1. Rekapitulasi Hasil Penerapan Discovery Learning

\begin{tabular}{|c|c|c|c|c|}
\hline No & Penelti & Judul & Tahun & Hasil \\
\hline 1. & $\begin{array}{l}\text { Vivi } \\
\text { Novita Sari } \\
\text { da } \\
\text { n Wahyu } \\
\text { Sukartinin } \\
\text { gsih }\end{array}$ & $\begin{array}{l}\text { Penerapan } \\
\text { Model } \\
\text { Discovery } \\
\text { learning } \\
\text { Sebagai } \\
\text { Upaya } \\
\text { Meningkatkan } \\
\text { Kemampuan } \\
\text { Menulis Teks } \\
\text { Cerita } \\
\text { Petualangan } \\
\text { Siswa Kelas } \\
\text { IV Sekolah }\end{array}$ & 2014 & $\begin{array}{l}\text { Berdasarkan data hasil pelaksanaan } \\
\text { pembelajaran discovery learning yang telah } \\
\text { dilakukan, tampak bahwa terjadi peningkatan } \\
\text { terhadap proses pelaksanaan pembelajaran dan } \\
\text { hasil belajar siswa. Dengan Pada siklus } 1 \text {, } \\
\text { aktivitas pembelajaran } 88,94 \% \text {. } \\
\text { Kemudian siklus II } 91,045 \% \text { dan peningkatan } \\
2,105 \% \text { dengan ketercapaian } \geq 80 \text {. Pada siklus } \\
\text { I rata-rata ketuntasan hasil belajar mencapai } \\
79,36 \text { dengan persentase ketuntasan klasikal } \\
73,07 \% \text {. Rata-rata ketuntasan } 84,09 \text { dengan } \\
\text { persentase ketuntasan klasikal } 84,61 \% \text {, } \\
\text { peningkatan sebesar } 11,54 \% \text {. }\end{array}$ \\
\hline 2. & $\begin{array}{l}\text { Agus } \\
\text { supriyadi }\end{array}$ & $\begin{array}{l}\text { Peningkatan } \\
\text { Hasil Belajar } \\
\text { Model } \\
\text { Discovery } \\
\text { Pembelajaran } \\
\text { Ipa }\end{array}$ & 2013 & $\begin{array}{l}\text { Berdasarkan analisis data hasil penilaian yang } \\
\text { dilakukan pada pelaksanaan pembelajaran } \\
\text { bentuk dan fungsinya melalui discovery pada } \\
\text { pembelajaran IPA terjadi peningkatkan hasil } \\
\text { belajar. Dengan pada siklus I hanya mampu } \\
\text { mencapai } 65,55 \% \text { dari aktivitas positif dan } \\
\text { terjadi peningkatan setelah siklus II menjadi } \\
\text { sebesar } 75,55 \% \text {. 3) dan untuk rata-rata nilai } \\
\text { evaluasi belajar siswa pada siklus I adalah } \\
\text { sebesar } 78,72 \text { dan terjadi peningkatan setelah } \\
\text { adanya perbaikan pembelajaran pada siklus II } \\
\text { menjadi } 97,76 \text {. }\end{array}$ \\
\hline 3. & $\begin{array}{l}\text { Widiadnya } \\
\text { na, Sadia } \\
\text { dan } \\
\text { Suastra }\end{array}$ & $\begin{array}{l}\text { Pengaruh } \\
\text { Model } \\
\text { Discovery } \\
\text { learning } \\
\text { Terhadap } \\
\text { Pemahaman } \\
\text { Konsep IPA } \\
\text { dan Sikap }\end{array}$ & 2014 & $\begin{array}{l}\text { Penelitian ini menghasilkan pengaruh terhadap } \\
\text { sikap dan nilai siswa yang semakin } \\
\text { meningkat. Dengan terdapat perbedaan } \\
\text { pemahaman konsep IPA dan sikap ilmiah } \\
\text { antara siswa yang belajar menggunakan model } \\
\text { discovery learning dengan siswa yang belajar } \\
\text { menggunakan model pengajaran langsung } \\
(\mathrm{F}=7,791 ; \mathrm{p}<0,05) \text {, (2) terdapat perbedaan }\end{array}$ \\
\hline
\end{tabular}




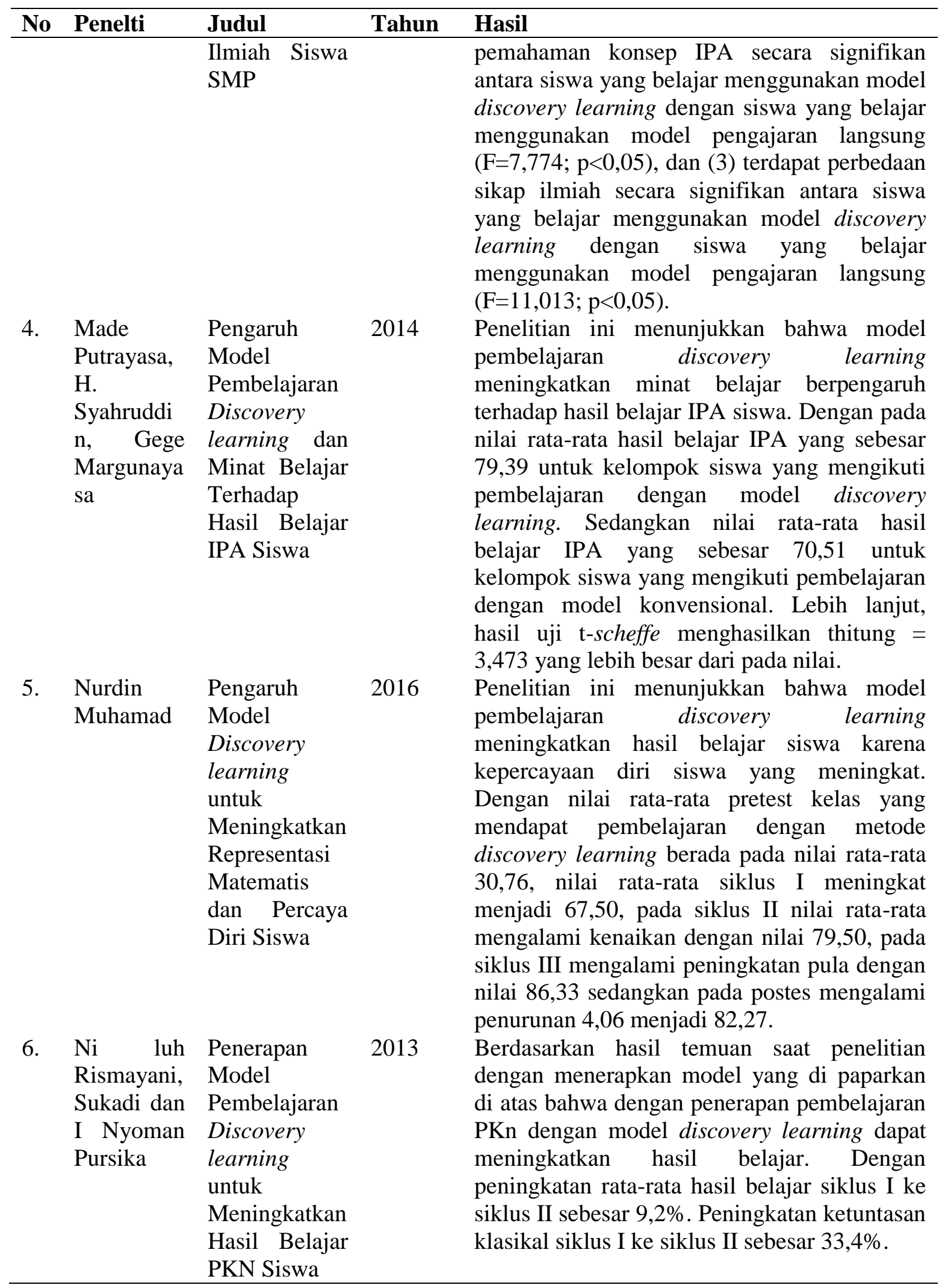

Dari kesembilan data hasil penelitian tersebut berkaitan dengan bagaimana dapat disimpulkan bahwa model discovery learning ini baik untuk digunakan di sekolah dasar terutama saat meningkatkan hasil belajar siswa. Sehingga dengan implementasi model discovery learning ini pada rencana pembelajaran yang dibuat guru dapat berdampak pada peningkatan hasil 
belajar siswa dari proses pembelajaran yang telah berlangsung.

\section{SIMPULAN DAN SARAN}

Berdasarkan penelitian dari beberapa sumber yang di atas dapat disimpulkan bahwa penerapan model discovery learning sangat membantu dalam upaya guru meningkatkan hasil belajar siswa. Tidak hanya itu model ini juga membantu dalam meningkatkan keaktifan guru dan siswa, kepercayaan diri siswa, dan kemampuan bekerja mandiri dalam pemecahan masalah. Selain itu model ini tidak hanya dapat diterapkan di sekolah dasar melainkan juga di tingkat pendidikan yang lebih tinggi yaitu Sekolah Menengah Pertama (SMP) dan Sekolah Menengah Atas (SMA).

Ucapan terima kasih peneliti berikan kepada semua pihak yang telah ikut adil dalam pembuatan artikel penelitian ini. Peneliti berharap semoga karya ini dapat diterima dan bermanfaat bagi pembaca. Peneliti menyadari bahwa dalam karya ini masih banyak kekurangan sehingga peneliti mengharapkan masukan yang dapat menjadi perbaikan kedepannya.

Harapan peneliti kedepannya yaitu model discovery learning ini semakin banyak diterapkan mengingat banyaknya kelebihan yang didapat dari penerapan model ini dalam kegiatan belajar mengajar mengajar.

\section{DAFTAR RUJUKAN}

Effendi, L. A. (2012). Pembelajaran matematika dengan model penemuan terbimbing untuk meningkatkan kemampuan representasi dan pemecahan masalah matematis siswa SMP. Jurnal Penelitian Pendidikan, 13 (2).

Kebudayaan, K. P. D. (2013). Model pembelajaran penemuan (discovery learning).

Muhamad, N. (2017). Pengaruh Metode Discovery learning untuk Meningkatkan Representasi Matematis dan Percaya Diri Siswa. Jurnal Pendidikan UNIGA, 10 (1), 9-22. Pembelajaran
Matematika. Jurnal Kependidikan:

Penelitian Inovasi Pembelajaran, 41 (1).

Purnomo, Y. W. (2011). Keefektifan Model Penemuan Terbimbing dan Cooperative Learning pada Pembelajaran Matematika. Jurnal Kependidikan: Penelitian Inovasi Pembelajaran, 41 (1).

Putrayasa, I. M., Syahruddin, S. P., \& Margunayasa, I. G. (2014). Pengaruh Model Pembelajaran Discovery Learning dan Minat Belajar terhadap Hasil Belajar IPA Siswa. MIMBAR PGSD Undiksha, 2 (1).

Rismayani, N. L. (2013). Penerapan Model Pembelajaran Discovery learning untuk Meningkatkan Hasil Belajar PKn Siswa. Jurnal Pendidikan Kewarganegaraan Undiksha, 1 (2).

Sari, V. N., \& Sukartiningsih, W. (2014). Penerapan Model Discovery learning Sebagai Upaya Meningkatkan Kemampuan Menulis Teks Cerita Petualangan Siswa Kelas IV Sekolah Dasar. Jurnal Penelitian Pendidikan Guru Sekolah Dasar, 2 (2).

Sinambela, P. N. (2017). Kurikulum 2013 dan Implementasinya dalam Pembelajaran. Generasi Kampus, 6 (2). 